\title{
Effects of Dessert Café Environmental Characteristics on Overall Quality, Brand Image and Loyalty
}

\author{
Byung-Kwan CHO ${ }^{1}$, Sung-Hoon KIM ${ }^{2}$, Debora LEE $^{3}$
}

Received: August 06, 2020. Revised: August 15, 2020. Accepted: August 30, 2020.

\begin{abstract}
Purpose: Along with the trend increasing dining-out and enjoying variety of menu, dessert café has been introduced as a new type of food service provider and grown up rapidly. We need to verify structural relationship that dessert café environment influences overall quality and brand image and loyalty. Research design, data, and methodology: This study seeks to understand how in-café environment influence overall quality, brand image and loyalty directly and indirectly based on SOR theory. We examine detail effect of in-café environment on overall quality and brand image and subsequently loyalty. Sample data were collected from 563 online survey panels and analyzed by using SmartPLS 3.2.9. Result: The results indicates that all sub-dimensions of in-café environment influences positively overall quality. While, menu and atmosphere make positive impact on brand image. price, food and beverage quality, employee service do not affect significantly brand image. Further, overall quality influences positively brand image and both overall quality and brand image affect positively loyalty. In addition, overall quality plays full mediator role in relationship among price, food and beverage quality, employee service and brand image. Conclusions: Dessert café should differentiate itself from competitors through physical and non-physical environments which are likely to influence overall quality. As overall quality mediates between environment and brand image and influences loyalty, dessert café is required to communicate strength of functional quality and service quality aggressively. Additionally, favorable brand image affecting loyalty is required to be dominated in advance as the market is likely to be segmented along with its growth.
\end{abstract}

Keywords : Environment, Overall quality, Brand image, Loyalty

JEL Classification Code: M30, M31, M37

\section{Introduction}

As dessert culture became popular in Korea due to the expansion of Western-style diet, the dessert market is spreading from women in their 20 s to 30 s to various age groups (Cho \& Jun, 2016). Dessert refers to desserts such as fruits and drinks that are provided to organize taste and

1 First Author, Doctoral Candidate, School of Business, Sejong University, Seoul, Korea, Email: jo423@naver.com

2 Second Author, Doctoral student, Graduate School of Business, Sejong University, Seoul, Korea. Email: 16121301@naver.com

3 Corresponding Author, Doctoral student, College of Human Science, Auburn University, Alabama, USA. Email: edvora92@gmail.com

() Copyright: The Author(s)

This is an Open Access article distributed under the terms of the Creative Commons Attribution Non-Commercial License (https://creativecommons.org/licenses/by-nc/4.0/) which permits unrestricted non-commercial use, distribution, and reproduction in any medium, provided the original work is properly cited. atmosphere after meals. Accordingly, the use of dessert cafes for light meals along with dessert menus such as coffee, tea, beverages, bakery, and ice cream is increasing. These dessert cafes are targeting the younger generation by using mixed meals that can be eaten not only after meals but also before meals and a light atmosphere.

After the coffee brand Starbucks entered Korea in 1999, various coffee chain brands such as Coffee Bean, Twosome Place, Pascucci, Angelinus, Tom and Toms, and Hollis were launched, and a dessert menu to be eaten with coffee appeared, as a result, the dissert cafe has grown explosively (Hwang \& Doh, 2009). Since then, the market competition is intensifying by adding growth with the addition of small and medium-sized franchise companies such as Ediya. On the other hand, recently, consumers visit coffee shops for various purposes, such as meeting, studying, and enjoying time alone, in addition to drinking coffee, so marketing to 
increase the value of in-store experience is becoming more important (Yu \& Fang, 2009). Therefore, in order to increase the experience value of consumers visiting the dessert cafe, it is necessary to establish a marketing strategy that improves the perceived quality and brand image by improving the in-store environment and increases loyalty.

According to SOR (Stimulus-Organism-Response) theory, environmental stimuli in stores consist of environmental and non-environmental cues (Baker, Parasuraman, Grewal, \& Voss, 2002), and emotional responses (e.g., positive and negative emotion), and consequently the behavioral intention (Mehrabian \& Russel, 1974). Many scholars are researching what is the environmental stimulus in the store and its concept. For example, Bitner (1992) defined the physical environment of a service company as a servicescape and argued that it is an objective and artificial environment that can be controlled by a company, as opposed to the natural and social environment. In addition, Baker, Levy, and Grewal (1992) explained the environmental stimulus at the service contact point as a servicescape, and Hightower Jr, Brady, and Baker (2002) defined the servicescape as a physical environment.

Bitner (1992) classified environmental dimensions into ambient environment (e.g. temperature, air quality, odor, music, noise), space/facilities (e.g. layout, equipment, furnishings), and signs, symbols, and artifacts (e.g. signage, artifacts, decoration style). Baker (1986) suggested store environment consists of social factors (e.g. employee), design factors (e.g. layout, cleanness, noise, space), and ambient factors (e.g. smell, lighting). Meanwhile, besides environmental cues, non-environmental factors also affect consumers' behavior such as extensive menu, food quality, price, value for money, and service (Clark \& Wood, 1998; Keyt, Yavas, \& Riecken, 1994). Since both physical and non-physical environmental factors can influence consumers' behavior, the current study defined environmental characteristics as menu, price, quality of food and drink, service, and atmosphere.

Environmental characteristics of dessert café have an effect on perceived overall quality and brand image. An overall quality is the embodiment of an attribute and feature of a product or service that can satisfy a consumer's desire (Chavan, 2003). The quality of a product and service is the attribute of performance (Johnson \& Fornell, 1991). Quality is a crucial factor that determines the purchase of a product and the intention of repurchase and perceived quality helps consumers to select a brand based on the product differentiation (Aaker, 1991). Brand image is a perception toward a brand formed by brand association (Keller, 1993), and consumers show a positive attitude and willingness to buy on products of a brand with a good image (Kamins \& Marks, 1991; Park, Jaworski, \& MacInnis, 1986). Consumer loyalty is viewed as a high commitment to continuously repurchase and repatronize a preferred product or service in the future (Oliver, 1999)., and is the most important determinant influencing the long-term achievement of a service company (Jones, 1996).

From this perspective, this study is to empirically examine the impact of environmental characteristics of dessert café on an overall quality, brand image, and loyalty based on S-O-R theory. The purposes and contributions of the current study are as follows.

First, most studies related to the environmental characteristics of restaurants were conducted on catering companies that provide food-oriented products and services such as general restaurants, family restaurants, fast food restaurants, and Korean buffets. However, studies related to the environmental characteristics of dessert cafes, a new type of catering business in which coffee and beverages, bakery, and ice cream are converged, are sparse, so this study in the context of dessert cafes is different from previous studies.

Second, the current study aims to verify that environmental characteristics are crucial factors that impacts overall quality, brand image and loyalty based on the framework of environmental characteristics-overall qualitybrand image-loyalty. However, research has been very insufficient from this perspective, especially few have been conducted the effect of environmental characteristics on brand image.

While many researchers investigated the relationship between physical environment and consumers' attitude and behavior, few studies analyzed the effect of environmental characteristics of store on consumer behavior. Filling this gap, this study expanded a scope of environmental characteristics and consumer behavior researches based on S-O-R theory.

The results of this study will provide theoretical and practical implications for the study of environmental characteristics of dessert cafes by suggesting to scholars and practitioners what methods to increase and manage the experience value of dessert cafe users.

\section{Literature Review}

\subsection{Environmental Characteristics}

The environmental characteristics of dessert cafes are physical/non-physical factors that influence consumers' perception in dessert cafes, including environmental and non-environmental cues. These environmental characteristics affect consumers' emotional reactions and behavioral intentions (Baker, Parasuraman, \& Grewal, 2002) and store selection (Walsh, Shiu, Hassan, Michaelidou, \& Beatty, 2011). 
In-store stimulus of dessert café is the concept that includes a variety of physical features such as merchandise, color, layout, music, noise, lighting, in-store promotions, employees, and other consumers (Kenhove \& Desrumaux, 1997). The perception and importance of a particular environmental dimension differ depending on a type of service organization (Bitner, 1992). Facility, atmosphere, human service, product characteristic, and promotion can be used as in-store cues (Lee, Lee, Kwon, \& Park, 2003). Meanwhile, Lee, Lee, Lee, and Babin (2008) classified environmental characteristics of festivalscape into three dimensions: ambient conditions (e.g. temperature, air quality, odors, music, noise), space/facilities (e.g. layout, equipment, furnishings), and signs, symbols, and artifacts (e.g. signage).

Restaurant environment is defined as physical environment that is developed or controlled by restaurant managers (Kim \& Moon, 2009). An attractive restaurant environment influences consumer satisfaction and future behavior since consumers are consciously or unconsciously affected by physical environment before, in the middle of, and after the meal (Han \& Ryu, 2009; Lin, 2004). Consumers consider physical environment as much as food and service quality during decision making for dining out (Lee, Lee, Lee, \& Babin, 2008). Therefore, convenient, creative, and innovative in-store designs of restaurants is a critical factor that influences continuous use leading to a positive evaluation and emotional reaction (Ryu \& Han, 2011; Wu \& Liang, 2009).

Beside physical cues in restaurants, a variety of menu, food quality, price, value for money, service factors impact the evaluation on a store as a crucial attribute in the selection of a service provider (Clark \& Wood, 1998; Keyt et al, 1994). In restaurants, consumers consider various attributes to be critical in decision making such as food quality, service quality, price, atmosphere, etc. (Liu \& Tse, 2018). Perceived service is a consumer's judgement on the overall excellence of service whether a store satisfied the expectations (Zeithaml, 1988). Besides service quality, food quality is a crucial determinant of customer's decision to revisit a restaurant (Qu, 1997). Food quality includes taste, a variety of menu, availability of healthy options, texture, appearance, etc. (Namkung \& Jang, 2007).

Ryu and Jang (2007) concluded that environmental cues (i.e. aesthetics, lighting, atmosphere, layout, eating utensils) have an effect on customer emotion in an upscale restaurant context. Jang and Namkung (2009) used space, design, color, and music as physical cues of full-service restaurants. Han and Ryu (2009) suggested the followings as essential environmental cues of restaurants: (1) decoration and artifacts, (2) space and layout, and (3) condition of atmosphere. Based on these studies, the current study defined environmental characteristics of dessert café consist of menu, price, quality of food and beverage, service, and atmosphere.

\subsubsection{Menu}

Food freshness and menu diversity are the most important factors influencing consumer satisfaction (Rozekhi, Hussin, Siddiqe, Rashid, \& Salmi, 2016). Therefore, restaurant managers must provide a variety of menus according to the preferences of consumers from different cultures, ethnicities and economic backgrounds. Menu variety is necessary to deal with customers' segmentalized preferences during dining out (Payne-Palacio \& Theis, 2005). Bernstein, Ottenfeld, and Witte (2008) explained that menu variability impacts consumer preferences in an upscale restaurant context. Knuston, Beck, and Elsworth (2006) found that friendliness, menu variety, location, and overall price are the crucial determinants of visiting restaurants. There are various attributes that considerably impact the tourists' during dining out such as attractive decorations, atmosphere, layout of menus, a variety of menus (Cohen \& Avieli, 2004).

Gordon (1992) insisted that menu variety, portion size, friendly people, quality of service, and value for money were the factors that made Chinese restaurants popular in the USA. In the restaurant context, Lewis (1981) suggested five factors as criteria for consumers' restaurant selection: food quality, menu variety, price, atmosphere, and convenience.

\subsubsection{Price}

Besides food quality, price is one of the major factors that impacts consumer behavior in the selection of place for dining out (Law, To, \& Goh, 2008). Price is a way to attract and sustain consumers (Hyun, 2010). A reasonable price has a positive influence on the evaluation for a dining experience (Andaleeb \& Conway, 2006). On the other hand, a high price compared to food and service quality have a negative effect on a consumer's decision to revisit in the future (Kim, Lee, \& Yoo, 2006).

\subsubsection{Food and Beverage Quality}

The extant literature explained that the major reason of dining out is to solve hunger and consequently food quality is an important determinant of dining out (Lo \& Lam, 2004; Peri, 2006). Food quality is evaluated based on taste, freshness, attractive food design, healthy ingredients, and proper temperature (Acebron \& Dopico, 2000; Namkung \& Jang, 2008). The quality of food and beverage is a crucial factor that determines dining experiences (Lo \& Lam, 2004; Sulek \& Hensley, 2004). As consumers are having more knowledge about products and services, a variety of menu options also impacts dining experiences (Ha \& Jang, 2010).

\subsubsection{Employee Service}

Since the interaction between the consumer and the service employee at the service point of contact affects the consumer's evaluation, many studies have suggested that the 
service quality of the employee is important in the process of selecting a place to eat out (Jang \& Namkung, 2009). Service employees' responsiveness, assurance, and empathy are important during interaction (Brady \& Robertson, 2001). Responsiveness refers to the help of the employee to accommodate the consumer's needs and demands regarding menu selection, and assurance means the confidence that consumers feel in the recommendation of the employee's menu, a safe feeling of food safety, and the ability to express opinions without fear. And empathy refers to showing sympathy and personalized attention (e.g., suggestions to help diet) to the mood and emotions of consumers (Stevens, Knutson, \& Patton, 1995).

\subsubsection{Atmosphere}

Atmosphere is an intangible characteristic of background that has an effect on the unconscious evaluation of environment (Han \& Ryu, 2009; Nguyen \& Leblanc, 2002). Atmosphere consist of temperature, lighting, noise, music, and odor (Han \& Ryu, 2009). For example, the environment with a pleasant odor induces more positive perception and evaluation of customers compared to the one with unpleasant odor (Morrison, Gan, Dubelaar, \& Oppewal, 2011). When a service facility provides a good atmosphere, there is a high possibility that consumers show positive behaviors such as willingness to stay longer and to spend more (Han \& Ryu, 2009; Nguyen \& Leblanc, 2002). Ryu and Jang (2007) found that environmental cues such as aesthetics, lighting, atmosphere, layout and dining utensils of restaurant facilities affect consumer emotions. Han and Ryu (2009) suggested the followings as essential environmental cues of restaurants: (1) decoration and artifacts, (2) space and layout, and (3) condition of atmosphere.

\subsection{Overall Quality}

Perceived overall quality is a consumer's evaluation of overall excellence and excellence in products and services (Parasuraman, Zeithaml, \& Berry, 1985; 1988). In food service industry, various environmental characteristics within a restaurant affect the overall quality evaluation of the restaurant's food and service. Hence, the overall evaluation of menu and service quality should be considered simultaneously in restaurant context.

Quality is a complex and multidimensional concept and the performance of a product or service that meets or exceeds customers' expectations (Waters \& Waters, 2008). Quality is excellence, value for money, conformance to specifications, and meeting customers' expectations (Reeves \& Bednar, 1994). Following Jahanshahi, Gashti, Mirdamadi, Nawaser, and Khaksar's (2011) study, when various environmental cues restaurant provides meets a consumer's expectation, he/she has a positive emotion toward a product and perceive its quality is high. Therefore, perceived overall quality is regarded as an important factor in marketing because it performs a crucial role in consumers' evaluation and process of decision making. Researchers suggest that the concept of quality includes perceived values and objective values (Holbrook \& Corfman, 1985; Zeithaml, 1987).

The perceived overall quality of a restaurant is a differentiating factor that helps consumers choose a restaurant. This means that benefits from a relatively high quality help to sustain a premium price and consequently increase profit and asset. Therefore, the perceived overall quality of the restaurant is the key to success and survival for corporations in a competitive environment. Most foodservice studies measured overall quality from the overall service perspective, but current study measure it from overall service and quality perspective.

\subsection{Brand Image}

Brand Image is a series of perceptions on a brand that a consumer formed by brand association (Keller, 1993). Brand image is a symbolic meaning that is reminded when a consumer experiences a certain attribute of a product or service (Padgett \& Allen, 1997). Brand image is a rational or emotional perception that a consumer associate with a certain brand (Low and Lamb, 2000). Brand image is a thought that immediately comes up in a consumer's mind (Ross, James, \& Vargas, 2006). Hence, brand image is a set of unique associations that brand strategies desire to establish and sustain (Aaker, 1991, 1996).

Brand image is one of major elements of brand asset that is the basis of brand success (Keller, 1993). Relatively stronger brand image plays a role of entry barrier since consumers mostly prefer a brand with strong image in decision making for purchase (Nikhashemi, Paim, Disin, \& Osman, 2013). Consumers reminds data in memory to make a decision for purchase and utilize brand image to organize and process it (Aaker, 1991).

Therefore, building a favorable brand image is essential for corporations to deliver an objective and position a brand (Lee, James, \& Kim, 2014). A good brand gives a friendly impression to consumers and strength the awareness toward products (Grewal, Krishnan, Baker, \& Borin, 1998). When a consumer has a strong image in mind, a product easily obtains an attraction and triggers desire to purchase (Shamma \& Hassan, 2011). Consumers are likely to have an amicable attitude and willingness to purchase towards a friendly product with a good brand image (Kamins \& Marks, 1991; Park, Jaworski, \& MacInnis, 1986). As a competitiveness of corporation (Linder \& Seidenstricker, 2010), brand image is a crucial asset that creates a profit and increases characteristics of a product (Ballantyne, Warren, \& Nobbs, 2006). 


\subsection{Loyalty}

Consumer loyalty is a high commitment to continuously repurchase and repatronize a preferred product or service in the future (Oliver, 1999). Also, brand loyalty is a consumer's attachment toward a brand (Kuscu \& Ozcam 2014). Said (2014) defined brand loyalty is emotional, evaluative, and behavioral reactions that are positively biased to a brand. A loyal consumer shows a commitment to a particular brand (Bloemer \& Kasper, 1995). Also, brand loyalty is the positive emotion of consumers who often use and purchase a certain brand in a long-term (Kocoglu, Tengilimoglu, Ekiyor, \& Guzel, 2015). Loyal customers are willing to recommend a service provider and to spread a positive word-of-mouth (Akamavi, Mohamed, Pellmann, \& Xu, 2015; Kumar, Dalla Pozza, \& Ganesh, 2013).

Researchers and marketing practitioners have investigated an effective way to enhance loyalty and antecedents of loyalty (Lee, Lee, \& Feick, 2001; Yang \& Patterson, 2004). Many researchers classified loyalty into attitudinal and behavioral dimensions (Guenzi \& Pelloni, 2004). While attitudinal dimension focuses on a consumer's willingness to repurchase and recommend, behavioral dimension focuses on a repeated purchasing and use frequency of a product and service (Wong \& Sohal, 2003). A decision making to repurchase due to convenience might not be an appropriate indicator of loyalty (Chiou \& Shen, 2006). However, in the hospitality industry, attitudinal dimension has been used as a measurement of customer loyalty (Han \& Ryu, 2009; Mattila, 2001; Schall, 2003). In comparison with manufacturing industry, a consumer's attitudinal and emotional commitments toward providers of products or services are important in hospitality industry (Schall, 2003). Therefore, in this study, customer loyalty is measured from the attitudinal perspective.

\section{Hypotheses}

\subsection{The relationship between environmental characteristics and overall quality}

Consumers can infer the quality of service from the service environment (Pollack, 2009; Wall \& Berry, 2007). Hooper, Coughlan, and Mullen (2013) found that servicescape and employee's service quality influence an overall service quality. Wakefield and Blodgett (1996) found that servicescape (e.g. layout, facility aesthetics, seating comfort, and facility cleanliness) affected perceived quality. A well-designed layout has a direct effect on a customer's quality perception and an indirect effect on the customer's desire to return (Wakefield \& Blodgett, 1994). As a servicescape, physical environment is the crucial element of perceived service quality and customer satisfaction (Jang \& Namkung, 2009; Ryu \& Han, 2010).

In a comparative study between department store and family restaurant, Yi and Kim (1998) defined physical environmental characteristics as accessibility, aesthetic, cleanness, and convenience. They empirically investigated how physical environments of service affects an overall quality. Also, the results of study showed that perceived service quality is influenced by aesthetic, cleanness, and convenience in department stores while it is impacted by accessibility and aesthetic in family restaurants.

Cues such as price, brand, advertising, word-of-mouth, and certain tangible service elements (physical facilities) are important to consumers who attempt to judge the quality of a restaurant prior to consumption (Parasuraman, Zeithaml, \& Berry, 1985). Since consumers infer restaurant quality based on food and beverage, quality of food and beverage is an important factor in the process of decision making (Kim, Shon, \& Lee, 2003). Therefore, we propose that restaurant's environmental characteristics influence over quality as follows:

H1: Environmental characteristics positively influences overall quality.

H1-1: Menu positively influences an overall quality.

H1-2: Price positively influences an overall quality.

H1-3: Food and beverage qualities positively influence an overall quality.

H1-4: Employee service positively influences an overall quality.

H1-5: Atmosphere positively influences an overall quality.

\subsection{The relationship between environmental characteristics and brand image}

Physical environments of a service company have a significant impact in building a positive company image and in communicating their image and service objectives with customers (Bitner, 1992), because they provide an informative cue about quality or assortment before a consumer purchase a service (Shostack, 1977). Many researchers found that physical environments influence store image and purchase behavior in hotels, restaurants, banks, retail stores, and hospitals (Upah \& Fulton, 1985; Zeithaml, Parasuraman, \& Berry, 1985).

Physical environments contribute greatly to the development of positive place brand image. According to Booms and Bitner (1982), servicescape has a significant impact on revisit intention of consumer and brand image of restaurants. They claimed that physical environment of hotel and restaurant strengths and reposition brand image and they 
can be effectively utilized to directly increase consumer satisfaction at a service encounter. Baker, Grewal, and Parasuraman (1994) revealed that physical environments significantly improve brand image and stimulate purchase behavior.

Tse, Sin, and Yim (2002) found that customer perceive high quality and amicable image when a restaurant is very crowded. Also, they examined the positive relationship between food quality and restaurant image. Ryu, Han, and Kim (2008) confirmed that food quality, service quality, interior design and decoration, restaurant location, and waiting time are key drivers of restaurant image. Nguyen and Leblanc (1998) proved that service quality is an antecedent of corporation image. Also, as consumers perceive higher service quality, they form a higher level of brand image in their mind.

Ostrowski, O'Brien, and Gordon (1993) explained that various positive experiences ultimately develop a positive image. Among many components that consist consumption experience, service quality is extremely important in the restaurant industry. Consequently, it is a rational expectation that service quality influences restaurant image. Hence, we hypothesize as follows:

H2: Environmental characteristics positively influences brand image.

H2-1: Menu positively influences brand image.

H2-2: Price positively influences brand image.

H2-3: Food and beverage qualities positively influence brand image.

H2-4: Employee service positively influences brand image. H2-5: Atmosphere positively influences brand image.

\subsection{The relationship between overall quality, brand image, and loyalty}

A good evaluation of consumer quality reinforces a positive brand image because it is strong, friendly, and increases unique brand association (Keller, 1993). The fact that perceived quality positively influences the image of products, services and places has been found in various contexts such as airlines (Zins, 2001), department stores (Ranjbarian, Sanayei, Kaboli, \& Hadadian, 2012), and restaurants (Ryu, Lee, \& Kim, 2012).

If the consumer's evaluation of quality is high, the consumer's behavioral intention will be favorable, so quality is sometimes described as a concept similar to the attitude that induces behavioral intention (Cronin \& Taylor, 1992; Zeithaml, Berry, \& Parasuraman, 1996). Parasuraman, Zeithaml, and Berry (1988) explained that there is a significant positive relationship between quality and recommendation intention. Boulding, Kalra, Staelin, and Zeithaml (1993) confirmed a positive relationship between perceived quality and repurchase intention, positive word of mouth, and behavioral intention including recommendation intention. These studies suggest that quality is a major factor in behavior related to consumer loyalty.

There are numerous studies that proved brand image has a direct or indirect relationship with loyalty. Brand image has a direct effect on brand loyalty (Merrilees \& Fry, 2002). Also, Selnes (1993) found corporate brand image has a direct impact on brand loyalty and brand reputation has the strongest effect on brand loyalty. In the restaurant context, the image of restaurant is a determinant of consumer satisfaction and behavioral intention (Ryu, Han, \& Kim, 2008).

In the full-service restaurant context, Jin, Lee, and Huffman (2012) found that a development of positive brand image impacts loyalty. Ryu, Han, and Kim (2008) found that a restaurant's image can be a predictor for both customers' satisfaction and behavioral intentions. In the grocery retailing sector, Martenson (2007) examined the influence of a corporate store's image on customer satisfaction and loyalty. In addition, many studies have shown that brand loyalty is determined by brand image (e.g., Brunner, Stöcklin, \& Opwis, 2008; Park, Robertson, \& Wu, 2004). Thus, we hypothesize as follows:

H3: Overall quality positively influences brand image.

H4: Overall quality positively influences loyalty.

H5: Brand image positively influences loyalty.

\section{Methodology}

\subsection{Data Collection}

The data was collected from dessert café customers who visited and purchased at least once within the last month in order to examine how visiting experience affected to their decision. We conducted online survey through a leading internet research company in South Korea. A total of 590 panelists responded. Of those responded surveys, 27 were not used due to irrelevant content and missing information, resulting in 563 as the final sample size. The sample size is sufficient because it is larger than 10 times the largest number of structural paths in the structural model.

\subsection{Measures}

All items were measured on a 7-point Likert-type scale ranging from 1 = 'strongly disagree' to 7 = 'strongly agree' (see Appendix 1)

Five dimensions of environmental characteristics such as menu ( 8 items), price (4 items), employee service (6 items), food and beverage ( 2 items), atmosphere ( 8 items), were 
measured with 28 items adapted from Kim, Lee, Kwon, and Kim (2004), Bitner (1990), Kim, Shon, and Lee (2003), Lee, Lee, Kwon, and Park (2003), and Sherman, Mathur, and Smith (1997). Overall quality was measured using 6 items (Lee, Jeong, \& Yoo, 2008; Butcher, Sparks, \& O'Callaghan, 2003; Iacobucci \& Ostrom, 1993). Brand image was measured using 4 items adopted and revised from Zimmer and Golden (1988) and Park and Suk (2011). Finally, loyalty was measured based on Lee, Back, and Kim (2009) and Zeithaml, Berry, and Parasuraman's (1996) study.

\section{Results}

\subsection{Demographic Characteristics of Samples}

Table 1 presents the demographic profiles of 563 respondents. There were slightly more females (50.6\%) than males (49.4\%). In terms of educational level, 51.9\% graduated 4-year college, followed by high school $(21.0 \%)$, 2 -year college (16.2\%), and graduate school $(10.5 \%)$.

Table 1: Demographic Profile of the Respondents $(n=563)$

\begin{tabular}{|c|c|c|c|}
\hline & Category & Frequency & $\%$ \\
\hline \multirow{2}{*}{ Gender } & Male & 278 & 49.4 \\
\hline & Female & 285 & 50.6 \\
\hline \multirow{5}{*}{ Age } & $20-29$ & 115 & 20.4 \\
\hline & $30-39$ & 114 & 20.2 \\
\hline & $40-49$ & 106 & 18.8 \\
\hline & $50-59$ & 115 & 20.4 \\
\hline & Over 60 & 113 & 20.1 \\
\hline \multirow{9}{*}{ Job } & Student & 45 & 8.0 \\
\hline & Office worker & 211 & 37.5 \\
\hline & Sales/Service & 39 & 6.9 \\
\hline & Engineer/Production & 29 & 5.2 \\
\hline & Public Official & 22 & 3.9 \\
\hline & Professional & 50 & 8.9 \\
\hline & Owner & 50 & 8.9 \\
\hline & Housewife & 95 & 16.9 \\
\hline & Others & 22 & 3.9 \\
\hline \multirow{4}{*}{$\begin{array}{l}\text { Number of } \\
\text { monthly visits }\end{array}$} & 1 & 80 & 14.2 \\
\hline & $2-3$ & 234 & 41.6 \\
\hline & $4-5$ & 110 & 19.5 \\
\hline & 6 or more times & 139 & 24.7 \\
\hline
\end{tabular}

The most prevalent job was office worker (20.4\%), followed by housewife $(16.9 \%)$, professional $(8.9 \%)$, owner
(8.9\%), and student $(8.0 \%)$. A majority of respondents were 20 's $(20.4 \%)$ and 50 's $(20.4 \%)$, followed by 30 's $(20.2 \%)$, 60 's $(20.1 \%)$, and 40 's $(18.8 \%)$. Lastly, the number of monthly visits of respondents was the most, 2-3 times (41.6\%), followed by more than 6 times (24.7), followed by 4-5 times (19.5\%).

\subsection{Assessment of Validity and Reliability}

In order to assess validity and reliability, we conducted confirmatory factor analysis with SmartPLS 3.2.9 program. As shown in Appendix 1, factor loadings range from .648 to .949 .

Also, average variance extracted (AVE) of menu, price, food and beverage quality, employee service, atmosphere, overall quality, brand image, and loyalty are $.663, .885$, $.891, .766, .669, .808, .837$, and .844 , respectively. Both factor loadings and AVE exceed .5, indicating convergent validity is confirmed.

The Cronbach's $\alpha$ values of menu, price, food and beverage quality, employee service, atmosphere, overall quality, brand image, and loyalty are $.926, .957, .878, .938$, $.929, .953, .935$, and .907 respectively. Meanwhile, composite reliability (CR) of each factor is $.940, .969, .942$, $.951, .942, .962, .954$, and $.942 .$, respectively. Therefore, reliability is established, because Cronbach's $\alpha$ and CR were larger than .7.

In addition, the square root of AVE is larger than other correlation values (Fornell \& Larcker, 1981) (See Appendix 2). Furthermore, the heterotrait-monotrati (HTMT) ratio of correlations values are under .900 ranging from .315 to .776 (Henseler, Ringle, \& Sarstedt, 2015). Hence, discriminant validity is confirmed. Meanwhile, the values of variance inflation factor (VIF) ranged from 1.309 to 2.525 , which is far below 3.3, indicating common method bias (CMB) (Kock, 2015) and multicollinearity (Hair, Hult, Ringle, \& Sarstedt, 2017) are not problematic.

\subsection{Assessment of Structural Model}

The following criteria were used to assess the structural model with SmartPLS 3.2.9. First, the predictive power of the model was assessed using the variance explained $\left(\mathrm{R}^{2}\right)$. $\mathrm{R}^{2}$ values of overall quality (.485), brand image (.553), and loyalty (.535) are higher than .1, indicating predictive power is confirmed (Falk \& Miller, 1992). Second, the predictive relevance of the endogenous constructs was assessed using the Stone-Gresser test $\left(\mathrm{Q}^{2}\right)$ which explains construct crossvalidated redundancy. $\mathrm{Q}^{2}$ of overall quality (.387), brand image (.456), and loyalty (.447) are over 0 , indicating the prediction relevance of the model is achieved. Finally, the overall model fit was assessed using the value of standardized root mean square residual (SRMR). The SRMR 
is .058 , which is lower than the cut-off threshold of .1 or .08 , indicating the structural model fit is a good. The values of $\mathrm{R}^{2}$ and $\mathrm{Q}^{2}$ are listed in Appendix 4

\subsection{Hypotheses Testing}

H1 states that environmental characteristics would directly influence overall quality. Menu $(\beta=.231$, t-value $=$ $4.344, \mathrm{p}<.001)$, price $(\beta=.123$, t-value $=3.078, \mathrm{p}<.01)$, food and beverage quality $(\beta=.117, \mathrm{t}$-value $=2.392, \mathrm{p}$ $<.05)$, employee service $(\beta=.151, \mathrm{t}$-value $=3.217, \mathrm{p}$ $<.001)$, and atmosphere $(\beta=.256$, t-value $=4.551, \mathrm{p}<.001)$ significantly influence overall quality. Therefore, H1-1 H1-5 were supported.

$\mathrm{H} 2$ posits that environmental characteristics would directly impact brand image. Menu $(\beta=.118$, $\mathrm{t}$-value $=$ $2.334, \mathrm{p}<.05)$ and atmosphere $(\beta=.200, \mathrm{t}$-value $=3.821, \mathrm{p}$ $<.001)$ significantly influence brand image. Therefore, H2-1 and $\mathrm{H} 2-5$ were supported. On the other hand, price $(\beta=.030$, $\mathrm{t}$-value $=.796, \mathrm{n} . \mathrm{s})$, food and beverage quality $(\beta=-.010$, tvalue $=.215, \mathrm{n} . \mathrm{s})$, and employee service $(\beta=.029$, t-value $=.524, \mathrm{n} . \mathrm{s})$ did not influence brand image, not supporting $\mathrm{H} 2-2, \mathrm{H} 2-3$, and $\mathrm{H} 2-5$.

H3 - 4 address that overall quality would directly influence brand image and loyalty. Overall quality significantly influences brand image $(\beta=.496$, t-value $=$ $10.572, \mathrm{p}<.001)$ and loyalty $(\beta=.369, \mathrm{t}$-value $=7.461, \mathrm{p}$ $<.001$ ). Therefore, $\mathrm{H} 3$ and $\mathrm{H} 4$ were supported.

H5 hypothesizes brand image would directly affect loyalty. Brand image $(\beta=.422, \mathrm{t}$-value $=8.590, \mathrm{p}<.001)$ significantly influences loyalty, supporting H5.

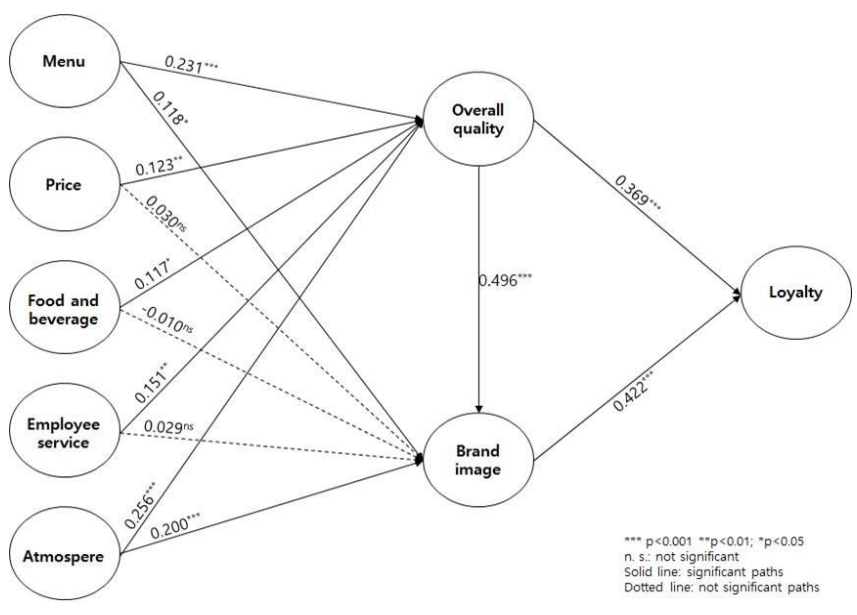

Figure 1: Estimates of the Structural Model

\subsection{Analysis of Effect Size}

The relative effect of the independent variable on the dependent variable was assessed using the effect size $\left(\mathrm{f}^{2}\right)$
(Chin, 1998). The values of .35, .15, and .02 represent large, medium, and small, respectively (Cohen, 1988). As shown in Appendix 4, the effect size of menu (.058), price (.022), atmosphere (.050) on overall quality are small. The effect size of food and beverage quality (.012) and employee service (.019) are very weak. While menu (.017), price (.002), food and beverage quality (.000), and employee service (.0001) have very weak effect size on brand image, atmosphere (.034) has small effect size on brand image. The effect size of overall quality on brand image (.283) and loyalty (.147) are moderate and small respectively. Finally, brand image (.191) have moderate effect size on loyalty.

\subsection{Analysis of Mediating Effect}

This study tested mediating effect of two factors using a bootstrapping test: (1) mediating role of overall quality between environment characteristics and brand image and (2) mediating role of brand image between and loyalty (See Appendix 5).

The results showed that overall quality has a partial mediating role in the relationship between menu $(\beta=.114$, tvalue $=4.148, \mathrm{p}<.001)$, atmosphere $(\beta=.127$, $\mathrm{t}$-value $=$ $4.147, \mathrm{p}<.001)$, and brand image. On the other hand, it has a full mediating role in the relationship between price $(\beta$ $=.061, \mathrm{t}$-value $=2.937, \mathrm{p}<.01)$, food and beverage quality $(\beta=.058, \mathrm{t}$-value $=2.380, \mathrm{p}<.05)$, employee service $(\beta$ $=.075, \mathrm{t}$-value $=2.967, \mathrm{p}<.01)$, and brand image. Also, brand image plays a partial mediating role between overall quality and loyalty $(\beta=.209, \mathrm{t}$-value $=7.090, \mathrm{p}<.001)$.

\section{Conclusion}

The current study examined how environmental characteristics of dessert café impact overall quality, brand image, and loyalty based on SOR theory. We developed the structural model to identify relationships between environmental characteristics, overall quality, brand image, and loyalty and provide strategic ideas for dessert café managers. The findings and theoretical and managerial implications are as follows.

\subsection{Theoretical implications}

First, previous studies focused on dining restaurants such as restaurant, family restaurant, fast food, and Korean buffet. However, research has been insufficient in the context of dessert café combined type of coffee and beverage, bakery, and ice cream. Filling this gap, this study examined the proposed model in the context of dessert café where consumers can conveniently enjoy and communicate using SOR theory. 
Second, the results showed menu, price, food and beverage, employee service, and atmosphere significantly impact overall quality. Also, menu and atmosphere affect brand image. In addition, overall quality influences both brand image and loyalty. Furthermore, brand image has a positive relationship with loyalty. Findings suggest that indesert café environmental characteristics jointly impact consumer responses toward desert café brands. In other words, the study shows that how consumers use in-desert café environmental characteristics have a major impact on their desert café quality which is directly related to brand image and loyalty.

Third, this study adds to our understanding of inrestaurant consumer responses and behaviors by investigating the relationship between overall quality and brand image, which explain a successful brand - consumer interaction, resulting in increasing loyalty. In particular, the results of this study prove that the framework of environmental characteristics-overall quality-brand imageloyalty is useful as it shows that overall quality plays a full or partial mediating role in the relationship between environmental characteristics and brand image and loyalty.

\subsection{Managerial implications}

The managerial implications of this study are as follows.

First, overall quality is significantly influenced by menu, price, food and beverage quality, employee service, and atmosphere. Therefore, dessert cafés should make an effort to differentiate in physical and non-physical environment perspective. In consideration of high attention on diet, dessert café managers should develop healthy dessert menus. Also, they should not only strength appropriateness and fairness of price but also enhance consumers' perception on quality by eliminating risks of food supply quality and sanitary condition. In addition, dessert cafés should advertise as a casual place to communicate by improving physical environments such as music, odor, layout, and interior.

Second, the findings show that overall quality is influenced by environmental characteristics that impact brand image and loyalty. Hence, dessert cafés should adopt overall quality assurance system for food supply, cooking process, and service and subsequently promote the safety to improve trust on overall quality and service quality.

Third, the results of this study show that brand image is a critical factor that enhances customer loyalty along with overall quality. This explains the importance of creating a brand image that reminds you of your own unique brand in the continuously growing dessert cafés market. Therefore, dessert cafés marketers need to build a brand image that differentiates them from competitors by using environmental characteristics for each target market. For example, as consumers recently pursue health and enjoyment at the same time, marketers may position their dessert cafés as a platform that provides practical and hedonistic values of health and pleasure.

Lastly, although dessert café market is expected to grow, few brands have a unique brand association. Dessert cafés should develop a positive brand image of healthy and pleasure to attract loyal customers.

\subsection{Limitations and future research directions}

The followings are the limitations of this study. First, this study is conducted in the context of a dessert café, and there is a limitation in generalizing the results of the study. Therefore, future study should be conducted in a comparative study of various industries such as luxury restaurant, regular restaurant, and fast food. Second, this study classified environmental characteristics into menu, price, quality, employee service, and atmosphere. Future research needs to consider other factors such as location, sanitation, eco-friendly food ingredients.

Lastly, most of customers are younger generations and female. Thus, future research can contribute to literature of dessert café by comparing the effect of environmental characteristics on attitude and purchase behavior depending on gender and age group.

\section{References}

Aaker, D. A. (1996). Building strong brands. New York: Free Press.

Aaker, D.A. (1991). Managing brand equity. The Free Press: New York, NY.

Acebron, L. B., \& Dopico, D. C. (2000). The importance of intrinsic and extrinsic cues to expected and experienced quality: An empirical application for beef. Food Quality and Preference, 11(3), 229-238.

Akamavi, R. K., Mohamed, E., Pellmann, K., \& Xu, Y. (2015). Key determinants of passenger loyalty in the low-cost airline business. Tourism Management, 46, 528-545.

Andaleeb, S. S., \& Conway, C. (2006). Customer satisfaction in the restaurant industry: An examination of the transactionspecific model. Journal of Services Marketing, 20(1), 3-11.

Baker, J. (1986). The role of the environment in marketing services: The consumer perspective. The Services Challenge: Integrating for Competitive Advantage, 1(1), 79-84.

Baker, J., Grewal, D., \& Parasuraman, A. (1994). The influence of store environment on quality inferences and store image. Journal of the Academy of Marketing Science, 22(4), 328-339.

Baker, J., Levy, M., \& Grewal, D. (1992). An experimental approach to making retail store environmental decisions. Journal of Retailing, 68(4), 445-460.

Baker, J., Parasuraman, A., Grewal, D., \& Voss, G. B. (2002). The influence of multiple store environment cues on perceived merchandise value and patronage intentions. Journal of Marketing, 66(2), 120-141. 
Ballantyne, R., Warren, A., \& Nobbs, K. (2006). The evolution of brand choice. Journal of Brand Management, 13(4-5), 339352.

Bernstein, D., Ottenfeld, M., \& Witte, C. L. (2008). A study of consumer attitudes regarding variability of menu offerings in the context of an upscale seafood restaurant. Journal of Foodservice Business Research, 11(4), 398-411.

Bitner, M. J. (1990). Evaluating service encounters: The effects of physical surroundings and employee responses. Journal of Marketing, 54(2), 69-82.

Bitner, M. J. (1992). Servicescapes: The impact of physical surroundings on customers and employees. Journal of Marketing, 56(2), 57-71.

Bloemer, J. M., \& Kasper, H. D. (1995). The complex relationship between consumer satisfaction and brand loyalty. Journal of Economic Psychology, 16(2), 311-329.

Booms, B. H., \& Bitner, M. J. (1982). Marketing services by managing the environment. Cornell Hotel and Restaurant Administration Quarterly, 23(1), 35-40.

Boulding, W., Kalra, A., Staelin, R., \& Zeithaml, V. A. (1993). A dynamic process model of service quality: From expectations to behavioral intentions. Journal of Marketing Research, 30(1), 7-27.

Brady, M. K., \& Robertson, C. J. (2001). Searching for a consensus on the antecedent role of service quality and satisfaction: An exploratory cross-national study. Journal of Business Research, 51(1), 53-60.

Brunner, T. A., Stöcklin, M., \& Opwis, K. (2008). Satisfaction, image, and loyalty: New versus experienced customers. European Journal of Marketing, 42(9/10), 10951105 .

Butcher, K., Sparks, B., \& O'Callaghan, F. (2003). Beyond core service. Psychology \& Marketing, 20(3), 187-208.

Chavan, R. B. (2003). Manual on quality assurance for Khadi. Mahatma Gandhi Institute of Rural Industrialization a Collaborative Project of KVIC \& IITD.

Chin, W. W. (1998). The partial least squares approach to structural equation modeling. Modern Methods for Business Research, 295(2), 295-336.

Chiou, J. S., \& Shen, C. C. (2006). The effects of satisfaction, opportunism, and asset specificity on consumers' loyalty intention toward internet portal sites. International Journal of Service Industry Management, 17(1), 7-22.

Cho, S. Y., \& Jun, J. K. (2016). Positioning analysis of dessert cafe based on brand personality. The Tourism Science Society of Korea, 40(4), 29-42.

Clark, M. A., \& Wood, R. C. (1998). Consumer loyalty in the restaurant industry-a preliminary exploration of the issues. International Journal of Contemporary Hospitality Management, 10(4), 139-144.

Cohen, E., \& Avieli, N. (2004). Food in tourism: Attraction and impediment. Annals of Tourism Research, 31(4), 755-778.

Cohen, J. (1988). Statistical Power Analysis for the Behavioral Sciences, Hilsdale. NJ: Lawrence Earlbaum Associates, 2.

Cronin Jr, J. J., \& Taylor, S. A. (1992). Measuring service quality: A reexamination and extension. Journal of Marketing, 56(3), 55-68.

Falk, R. F. and N. Miller (1992). A primer for soft modeling, Akron, Ohio: University of Akron Press.
Fornell, C., \& Larcker, D. F. (1981). Evaluating structural equation models with unobservable variables and measurement error. Journal of Marketing Research, 18(1), 3950.

Gordon, E. (1992). Annual CREST report. Restaurants USA, 12(10), 39-40.

Grewal, D., Krishnan, R., Baker, J., \& Borin, N. A. (1998). The effect of store name, brand name and price discounts on consumers' evaluations and purchase intentions. Journal of Retailing, 74(3), 331.

Guenzi, P., \& Pelloni, O. (2004). The impact of interpersonal relationships on customer satisfaction and loyalty to the service provider. International Journal of Service Industry Management, 15(4), 365-384.

Ha, J., \& Jang, S. S. (2010). Perceived values, satisfaction, and behavioral intentions: The role of familiarity in Korean restaurants. International Journal of Hospitality Management, 29(1), 2-13.

Hair, J. F., Hult, G. T. M., Ringle, C., \& Sarstedt, M. (2017). A primer on partial least squares structural equation modeling (PLS-SEM). Thousand Oaks, CA: Sage Publications.

Han, H., \& Ryu, K. (2009). The roles of the physical environment, price perception, and customer satisfaction in determining customer loyalty in the restaurant industry. Journal of Hospitality \& Tourism Research, 33(4), 487-510.

Henseler, J., Ringle, C. M., \& Sarstedt, M. (2015). A new criterion for assessing discriminant validity in variance-based structural equation modeling. Journal of the Academy of Marketing Science, 43(1), 115-135.

Hightower Jr, R., Brady, M. K., \& Baker, T. L. (2002). Investigating the role of the physical environment in hedonic service consumption: an exploratory study of sporting events. Journal of Business Research, 55(9), 697-707.

Holbrook, M. B. \& Corfman, K. P. (1985). Quality and value in the consumption experience: Phaldrus rides again. In J.Jacoby and J. Olson (eds.), Perceived quality (pp. 31-57). Lexington, MA: Lexington Books.

Hooper, D., Coughlan, J., \& Mullen, M. R. (2013). The servicescape as an antecedent to service quality and behavioral intentions. Journal of Services Marketing, 27(4), 271-280.

Hwang, J. S., Doh, S. J. (2009). What is the meaning and usage patterns of branded coffee shops to consumers? Journal of Outdoor Advertising Research 6(3), 61-106.

Hyun, S. S. (2010). Predictors of relationship quality and loyalty in the chain restaurant industry. Cornell Hospitality Quarterly, 51(2), 251-267.

Iacobucci, D., \& Ostrom, A. (1993). Gender differences in the impact of core and relational aspects of services on the evaluation of service encounters. Journal of Consumer Psychology, 2(3), 257-286.

Jahanshahi, A. A., Gashti, M. A. H., Mirdamadi, S. A., Nawaser, K., \& Khaksar, S. M. S. (2011). Study the effects of customer service and product quality on customer satisfaction and loyalty. International Journal of Humanities and Social Science, 1(7), 253-260.

Jang, S. S., \& Namkung, Y. (2009). Perceived quality, emotions, and behavioral intentions: Application of an extended Mehrabian-Russell model to restaurants. Journal of Business Research, 62(4), 451-460. 
Jin, N., Lee, S., \& Huffman, L. (2012). Impact of restaurant experience on brand image and customer loyalty: Moderating role of dining motivation. Journal of Travel \& Tourism Marketing, 29(6), 532-551.

Johnson, M. D., \& Fornell, C. (1991). A framework for comparing customer satisfaction across individuals and product categories. Journal of Economic Psychology, 12(2), 267-286.

Jones, T. O. (1996). Why satisfied customers defect. Journal of Management in Engineering, 12(6), 11-11.

Kamins, M. A., \& Marks, L. J. (1991). The perception of kosher as a third party certification claim in advertising for familiar and unfamiliar brands. Journal of the Academy of Marketing Science, 19(3), 177-185.

Keller, K. L. (1993). Conceptualizing, measuring, and managing customer-based brand equity. Journal of Marketing, 57(1), 122.

Kenhove, P. V., \& Desrumaux, P. (1997). The relationship between emotional states and approach or avoidance responses in a retail environment. The International Review of Retail, Distribution and Consumer Research, 7(4), 351-368.

Keyt, J. C., Yavas, U., \& Riecken, G. (1994). ImportancePerformance Analysis. International Journal of Retail \& Distribution Management, 22(5), 35-40.

Kim, E. J., Lee, Y. -K., Kwon, Y. J., \& Kim, E. S. (2004). The Effect of Selected In-Restaurant Environment on Customer Satisfaction and Behavioral Intentions/Behaviors using Structural Equation Model: Mediating Roles of Customer's Emotions. Korea Customer Satisfaction Management Association, 6(1), 1-16.

Kim, E. J., Shon, D., \& Lee, Y. -K. (2003). The comparison of impacts of in-restaurant environment on perceived store quality in family restaurant context. International Journal of Tourism Sciences, 3(2), 115-132.

Kim, W. G., \& Moon, Y. J. (2009). Customers' cognitive, emotional, and actionable response to the servicescape: A test of the moderating effect of the restaurant type. International Journal of Hospitality Management, 28(1), 144-156.

Kim, W. G., Lee, Y. -K., \& Yoo, Y. J. (2006). Predictors of relationship quality and relationship outcomes in luxury restaurants. Journal of Hospitality \& Tourism Research, 30(2), 143-169.

Kock, N. (2015). Common method bias in PLS-SEM: A full collinearity assessment approach. International Journal of $e$ Collaboration, 11(4), 1-10.

Knutson, B., Beck, J., \& Elsworth, J. (2006). The two dimensions of restaurant selection important to the mature market. Journal of Hospitality \& Leisure Marketing, 14(3), 35-47.

Kocoglu, C., Tengilimoglu, D., Ekiyor, A., \& Guzel, A. (2015). The effects of brand loyalty on the consumer buying behaviors: The example of perfume in the province of Ankara. International Journal of Humanities and Management Sciences, 3(5), 318-323.

Kumar, V., Dalla Pozza, I., \& Ganesh, J. (2013). Revisiting the satisfaction-loyalty relationship: Empirical generalizations and directions for future research. Journal of Retailing, 89(3), 246-262.

Kuscu, A \& Ozcam 2014. Analyzing factors affecting repurchase intention during Gezi Park brand protests. European Journal of Business and Management, 6(38), 177-188.
Law, R., To, T., \& Goh, C. (2008). How do Mainland Chinese travelers choose restaurants in Hong Kong? An exploratory study of individual visit scheme travelers and packaged travelers. International Journal of Hospitality Management, 27(3), 346-354.

Lee, J. L., James, J. D., \& Kim, Y. K. (2014). A reconceptualization of brand image. International Journal of Business Administration, 5(4), 1-11.

Lee, J., Lee, J., \& Feick, L. (2001). The impact of switching costs on the customer satisfaction- loyalty link: Mobile phone service in France. Journal of Services Marketing, 15(1), 35-48.

Lee, Y.-K., Back, K. J., \& Kim, J. Y. (2009). Family restaurant brand personality and its impact on customer's emotion, satisfaction, and brand loyalty. Journal of Hospitality \& Tourism Research, 33(3), 305-328.

Lee, Y.-K., Jeong, Y. K., \& Yoo, D. K. (2008). The determinants of relationship commitment: Relational benefits, core quality, and relationship satisfaction. Academy of Customer Satisfaction Management, 10(1), 51-69.

Lee, Y.-K., Lee, D. H., Kwon, Y. J., \& Park, Y. K. (2003). The effects of in-store environment cues on purchase intentions across the three types of restaurants in Korea. International Journal of Tourism Sciences, 3(1), 79-93.

Lee, Y.-K., Lee, C. K., Lee, S. K., \& Babin, B. J. (2008). Festivalscapes and patrons' emotions, satisfaction, and loyalty. Journal of Business Research, 61(1), 56-64.

Lewis, R. C. (1981). Restaurant advertising-appeals and consumers intentions. Journal of Advertising Research, 21(5), 69-74.

Lin, I. Y. (2004). Evaluating a servicescape: The effect of cognition and emotion. International Journal of Hospitality Management, 23(2), 163-178.

Linder, C., \& Seidenstricker, S. (2010). The strategic meaning of ingredient brands: A resource-based analysis. Asian Journal of Marketing, 4(1), 1-16.

Liu, P., \& Tse, E. C. Y. (2018). Exploring factors on customers' restaurant choice: An analysis of restaurant attributes. British Food Journal, 120(10), 2289-2303.

Lo, A., \& Lam, T. (2004). Long-haul and short-haul outbound allinclusive package tours. Asia Pacific Journal of Tourism Research, 9(2), 161-176.

Low, G. S., \& Lamb, C. W. (2000). The measurement and dimensionality of brand associations. Journal of Product \& Brand Management, 9(6), 350-370.

Martenson, R. (2007). Corporate brand image, satisfaction and store loyalty: A study of the store as a brand, store brands and manufacturer brands. International Journal of Retail \& Distribution Management, 35(7), 544-555.

Mattila, A. S. (2001). Emotional bonding and restaurant loyalty. Cornell Hotel and Restaurant Administration Quarterly, 42(6), 73-79.

Mehrabian, A., \& Russell, J. A. (1974). An approach to environmental psychology. the MIT Press.

Merrilees, B., \& Fry, M. L. (2002). Corporate branding: A framework for e-retailers. Corporate Reputation Review, 5(23), 213-225.

Morrison, M., Gan, S., Dubelaar, C., \& Oppewal, H. (2011). Instore music and aroma influences on shopper behavior and satisfaction. Journal of Business Research, 64(6), 558-564. 
Namkung, Y., \& Jang, S. (2007). Does food quality really matter in restaurants? Its impact on customer satisfaction and behavioral intentions. Journal of Hospitality \& Tourism Research, 31(3), 387-409.

Namkung, Y., \& Jang, S. S. (2008). Are highly satisfied restaurant customers really different? A quality perception perspective. International Journal of Contemporary Hospitality Management, 20(2), 142-155.

Nguyen, N., \& LeBlanc, G. (1998). The mediating role of corporate image on customers' retention decisions: An investigation in financial services. International Journal of Bank Marketing, 16(2), 52-65.

Nguyen, N., \& Leblanc, G. (2002). Contact personnel, physical environment and the perceived corporate image of intangible services by new clients. International Journal of Service Industry Management, 13(3), 242-262.

Nikhashemi, S. R., Paim, L., Sidin, S. M., \& Osman, S. (2013). The antecedents of brand equity development on Malaysian interment service providers. World Applied Sciences Journal, 25(1), 14-22.

Oliver, R. L. (1999). Whence consumer loyalty? Journal of Marketing, 63(4_suppl1), 33-44.

Ostrowski, P. L., O'Brien, T. V., \& Gordon, G. L. (1993). Service quality and customer loyalty in the commercial airline industry. Journal of Travel Research, 32(2), 16-24.

Padgett, D., \& Allen, D. (1997). Communicating experiences: A narrative approach to creating service brand image. Journal of Advertising, 26(4), 49-62.

Parasuraman, A., Zeithaml, V. A., \& Berry, L. L. (1985). A conceptual model of service quality and its implications for future research. Journal of Marketing, 49(4), 41-50.

Parasuraman, A., Zeithaml, V. A., \& Berry, L. L. (1988). SERVQUAL: A multiple-item scale for measuring consumer perc. Journal of Retailing, 64(1), 12-40.

Park, C. W., Jaworski, B. J., \& MacInnis, D. J. (1986). Strategic brand concept-image management. Journal of Marketing, 50(4), 135-145.

Park, J. W., Robertson, R., \& Wu, C. L. (2004). The effect of airline service quality on passengers' behavioural intentions: A Korean case study. Journal of Air Transport Management, 10(6), 435-439.

Park, J. Y., \& Suk, M. R. (2011). Influence of brand awareness and brand image of take-out coffee shop on the customers' satisfaction and loyalty. Korean Journal of Tourism Research, 26(1), 183-199.

Payne-Palacio, J., \& Theis, M. (2005). Introduction to foodservice (10th ed.). Upper Saddle River, NJ: Prentice-Hall.

Peri, C. (2006). The universe of food quality. Food Quality and Preference, 17(1-2), 3-8.

Pollack, B. L. (2009). Linking the hierarchical service quality model to customer satisfaction and loyalty. Journal of Services Marketing, 23(1), 42-50.

Qu, H. (1997). Determinant factors and choice intention for Chinese restaurant dining: A multivariate approach. Journal of Restaurant \& Foodservice Marketing, 2(2), 35-49.

Ranjbarian, B., Sanayei, A., Kaboli, M. R., \& Hadadian, A. (2012). An analysis of brand image, perceived quality, customer satisfaction and re-purchase intention in Iranian department stores. International Journal of Business and
Management, 7(6), 40-48.

Reeves, C. A., \& Bednar, D. A. (1994). Defining quality: Alternatives and implications. Academy of Management Review, 19(3), 419-445.

Ross, S. D., James, J. D., \& Vargas, P. (2006). Development of a scale to measure team brand associations in professional sport. Journal of Sport Management, 20(2), 260-279.

Rozekhi, N. A., Hussin, S., Siddiqe, A. S. K. A. R., Rashid, P. D. A., \& Salmi, N. S. (2016). The influence of food quality on customer satisfaction in fine dining restaurant: Case in Penang. International Academic Research Journal of Business and Technology, 2(2), 45-50.

Ryu, K., \& Han, H. (2010). Influence of the quality of food, service, and physical environment on customer satisfaction and behavioral intention in quick-casual restaurants: Moderating role of perceived price. Journal of Hospitality \& Tourism Research, 34(3), 310-329.

Ryu, K., \& Han, H. (2011). New or repeat customers: How does physical environment influence their restaurant experience? International Journal of Hospitality Management, 30(3), 599-611.

Ryu, K., \& Jang, S. S. (2007). The effect of environmental perceptions on behavioral intentions through emotions: The case of upscale restaurants. Journal of Hospitality \& Tourism Research, 31(1), 56-72.

Ryu, K., Han, H., \& Kim, T. H. (2008). The relationships among overall quick-casual restaurant image, perceived value, customer satisfaction, and behavioral intentions. International Journal of Hospitality Management, 27(3), 459-469.

Ryu, K., Lee, H. R., \& Kim, W. G. (2012). The influence of the quality of the physical environment, food, and service on restaurant image, customer perceived value, customer satisfaction, and behavioral intentions. International Journal of Contemporary Hospitality Management, 24(2), 200-223.

Said, H. (2014). Mobile phone brand loyalty and repurchase intention. European Journal of Business and Management, 6(26), 69-72.

Schall, M. (2003). Best practices in the assessment of hotel-guest attitudes. Cornell Hotel and Restaurant Administration Quarterly, 44(2), 51-65.

Selnes, F. (1993). An examination of the effect of product performance on brand reputation, satisfaction, and loyalty. European Journal of Marketing, 27(9), 19-35.

Shamma, H. M., \& Hassan, S. S. (2011). Integrating product and corporate brand equity into total brand equity measurement. International Journal of Marketing Studies, 3(1), 11.

Sherman, E., Mathur, A., \& Smith, R. B. (1997). Store environment and consumer purchase behavior: Mediating role of consumer emotions. Psychology \& Marketing, 14(4), 361378.

Shostack, G. L. (1977). Breaking free from product marketing. Journal of Marketing, 41(2), 73-80.

Stevens, P., Knutson, B., \& Patton, M. (1995). DINESERV: A tool for measuring service quality in restaurants. The Cornell Hotel and Restaurant Administration Quarterly, 36(2), 5-60.

Sulek, J. M., \& Hensley, R. L. (2004). The relative importance of food, atmosphere, and fairness of wait: The case of a fullservice restaurant. Cornell Hotel and Restaurant 
Administration Quarterly, 45(3), 235-247.

Tse, A. C. B., Sin, L., \& Yim, F. H. (2002). How a crowded restaurant affects consumers' attribution behavior. International Journal of Hospitality Management, 21(4), 449-454.

Upah, Gregory D. and James N. Fulton (1985). Situation classification in services marketing. in The Services Encounter, John A. Czepiel, Michael Soloman, and Carole Surprenant, eds. Lexington, MA: Lexington Books, 255-264.

Wakefield, K. L., \& Blodgett, J. G. (1994). The importance of servicescapes in leisure service settings. Journal of Services Marketing, 8(3), 66-76.

Wakefield, K. L., \& Blodgett, J. G. (1996). The effect of the servicescape on customers' behavioral intentions in leisure service settings. Journal of Services Marketing, 10(6), 45-61.

Wall, E. A., \& Berry, L. L. (2007). The combined effects of the physical environment and employee behavior on customer perception of restaurant service quality. Cornell Hotel and Restaurant Administration Quarterly, 48(1), 59-69.

Walsh, G., Shiu, E., Hassan, L. M., Michaelidou, N., \& Beatty, S. E. (2011). Emotions, store-environmental cues, store-choice criteria, and marketing outcomes. Journal of Business Research, 64(7), 737-744.

Waters, D., \& Waters, C. D. J. (2008). Quantitative methods for business. Pearson Education.

Wong, A., \& Sohal, A. (2003). Service quality and customer loyalty perspectives on two levels of retail relationships. Journal of Services Marketing, 7(5), 495-513.

Wu, C. H. J., \& Liang, R. D. (2009). Effect of experiential value on customer satisfaction with service encounters in luxury- hotel restaurants. International Journal of Hospitality Management, 28(4), 586-593.

Yang, Z., \& Peterson, R. T. (2004). Customer perceived value, satisfaction, and loyalty: The role of switching costs. Psychology \& Marketing, 21(10), 799-822.

Yi, Y., \& Kim, W. C. (1998). The influence of physical environment on service quality perception: A comparative study. Korean Marketing Review, 13(1), 61-86.

Yu, H., \& Fang, W. (2009). Relative impacts from product quality, service quality, and experience quality on customer perceived value and intention to shop for the coffee shop market. Total Quality Management, 20(11), 1273-1285.

Zeithaml, V. A. (1987). Defining and relating price, perceived quality, and perceived value. Cambridge, MA: Marketing Science Institute.

Zeithaml, V. A. (1988). Consumer perceptions of price, quality, and value: A means-end model and synthesis of evidence. Journal of Marketing, 52(3), 2-22.

Zeithaml, V. A., Berry, L. L., \& Parasuraman, A. (1996). The behavioral consequences of service quality. Journal of Marketing, 60(2), 31-46.

Zeithaml, V. A., Parasuraman, A., \& Berry, L. L. (1985). Problems and strategies in services marketing. Journal of Marketing, 49(2), 33-46.

Zimmer, M. R., \& Golden, L. L. (1988). Impressions of retail stores: A content analysis of consume. Journal of Retailing, 64(3), 265-293.

Zins, A. H. (2001). Relative attitudes and commitment in customer loyalty models. International Journal of Service Industry Management., 12(3), 269-294 


\section{Appendixes}

\begin{tabular}{|c|c|c|c|c|}
\hline Items & $\begin{array}{l}\text { Standardized } \\
\text { factor loadings }\end{array}$ & $\mathrm{CR}^{\mathrm{a}}$ & $\mathrm{AVE}^{\mathrm{b}}$ & Cronbach $\alpha$ \\
\hline Menu & & .940 & .663 & .926 \\
\hline New style menu is available in this dessert café. & .791 & & & \\
\hline Popular dessert menu is available in this dessert café. & .857 & & & \\
\hline Popular side menu is available in this dessert café. & .827 & & & \\
\hline Side menu other than food is available in this dessert café. & .648 & & & \\
\hline Various beverage and dessert brands are available in this dessert café. & .847 & & & \\
\hline Various beverage and dessert menus are available in this dessert café. & .858 & & & \\
\hline Jarious wine brands are available in this café. & .817 & & & \\
\hline Various menus are available in this café. & .845 & & & \\
\hline $\begin{array}{r}\text { Price } \\
\end{array}$ & & .969 & .885 & .957 \\
\hline Beverage price is appropriate in this dessert café. & .948 & & & \\
\hline Food price is appropriate in this dessert café. & .935 & & & \\
\hline Beverage price is fair in this dessert café. & .935 & & & \\
\hline Food price is fair in this dessert café. & .947 & & & \\
\hline Food and beverage & & .942 & .891 & .878 \\
\hline Beverage quality is good in this dessert café. & .946 & & & \\
\hline Food quality is good in this dessert café. & .941 & & & \\
\hline Employee service & & .951 & .766 & .938 \\
\hline Employees are willingly to assist consumers in this dessert café. & .851 & & & \\
\hline There are enough employees to serve in this dessert café. & .829 & & & \\
\hline Employees are kind in this dessert café. & .906 & & & \\
\hline Employees have abundant knowledge on menu in this dessert café. & .821 & & & \\
\hline mployees have good manners in this dessert café. & .922 & & & \\
\hline Employees respond quickly on consumer's request in this dessert café. & .916 & & & \\
\hline \begin{tabular}{|c|} 
Atmosphere \\
\end{tabular} & & .942 & .669 & .929 \\
\hline Color of this dessert café is good. & .846 & & & \\
\hline Pecoration of this dessert café is good. & .830 & & & \\
\hline Fragrance of this dessert café is good. & .838 & & & \\
\hline ayout of this dessert café is good. & .843 & & & \\
\hline ighting of this dessert café is good. & .815 & & & \\
\hline Music of this dessert café is good. & .767 & & & \\
\hline Size of this dessert café is enough. & .794 & & & \\
\hline Temperature of this dessert café is good. & .807 & & & \\
\hline \begin{tabular}{|c|} 
Overall quality \\
\end{tabular} & & .962 & .808 & .953 \\
\hline Food of this dessert café is high quality. & .887 & & & \\
\hline Food of this dessert café is first class quality. & .908 & & & \\
\hline Food quality of this dessert café is excellent. & .910 & & & \\
\hline Service quality of this dessert café is high. & .915 & & & \\
\hline Service quality of this dessert café is first class. & .895 & & & \\
\hline Pervice quality of this dessert café is excellent. & .879 & & & \\
\hline \begin{tabular}{|c|} 
Brand image \\
\end{tabular} & & .954 & .837 & .935 \\
\hline This dessert cafe's brand is unique. & .898 & & & \\
\hline This dessert cafe's brand has personality. & .938 & & & \\
\hline This dessert cafe's brand has differentiation. & .926 & & & \\
\hline This dessert cafe's brand has a special image. & .897 & & & \\
\hline \begin{tabular}{|c|} 
Loyalty \\
\end{tabular} & & .942 & .844 & .907 \\
\hline will recommend this dessert cafe to my friends and neighbors. & .930 & & & \\
\hline will say positive things about this dessert café to other people. & .949 & & & \\
\hline would like to visit this dessert cafe next time again. & .876 & & & \\
\hline
\end{tabular}

${ }^{\mathrm{a}} \mathrm{CR}$ (Composite Reliability), ${ }^{\mathrm{b}} \mathrm{AVE}$ (Average Variance Extracted) 
Appendix 2: Fornell-Larcker Criterion and Correlation Matrix

\begin{tabular}{|c|c|c|c|c|c|c|c|c|}
\hline & 1 & 2 & 3 & 4 & 5 & 6 & 7 & 8 \\
\hline Menu & .814 & & & & & & & \\
\hline Price & .298 & .941 & & & & & & \\
\hline Food and beverage quality & .584 & .479 & .944 & & & & & \\
\hline Employee service & .515 & .330 & .604 & .875 & & & & \\
\hline Atmosphere & .592 & .345 & .591 & .725 & .818 & & & \\
\hline Overall quality & .565 & .386 & .553 & .567 & .613 & .899 & & \\
\hline Loyalty & .528 & .489 & .584 & .558 & .611 & .668 & .919 & \\
\hline Brand image & .534 & .330 & .483 & .519 & .599 & .707 & .683 & .915 \\
\hline
\end{tabular}

Appendix 3: Heterotrait-Monotrait Ratio (HTMT)

\begin{tabular}{|c|c|c|c|c|c|c|c|c|}
\hline & $\mathbf{1}$ & $\mathbf{2}$ & $\mathbf{3}$ & $\mathbf{4}$ & $\mathbf{5}$ & $\mathbf{6}$ & $\mathbf{7}$ & $\mathbf{8}$ \\
\hline Menu & $\mathbf{1}$ & & & & & & & \\
\hline Price & .315 & 1 & & & & & & \\
\hline Food and beverage quality & .646 & .523 & 1 & & & & \\
\hline Employee service & .546 & .345 & .660 & 1 & & & & \\
\hline Atmosphere & .631 & .365 & .653 & .776 & 1 & & & \\
\hline Overall quality & .597 & .403 & .604 & .594 & .648 & 1 & & \\
\hline Loyalty & .573 & .525 & .655 & .603 & .663 & .717 & 1 & \\
\hline Brand image & .572 & .348 & .532 & .549 & .639 & .749 & .740 & 1 \\
\hline
\end{tabular}

\section{Appendix 4: Structural Estimates(PLS)}

\begin{tabular}{|c|c|c|c|c|c|c|}
\hline & Paths & Estimate & t-value & $\mathbf{p}$ & $f^{2}$ & Results \\
\hline $\mathrm{H} 1-1$ & Menu $\rightarrow$ Overall quality & .231 & $4.344^{* * *}$ & .000 & .058 & Supported \\
\hline $\mathrm{H} 1-2$ & Price $\rightarrow$ Overall quality & .123 & $3.078^{* *}$ & .002 & .022 & Supported \\
\hline $\mathrm{H} 1-3$ & Food and Beverage $\rightarrow$ Overall quality & .117 & $2.392^{*}$ & .017 & .012 & Supported \\
\hline $\mathrm{H} 1-4$ & Employee service $\rightarrow$ Overall quality & .151 & $3.217^{* *}$ & .001 & .019 & Supported \\
\hline $\mathrm{H} 1-5$ & Atmosphere $\rightarrow$ Overall quality & .256 & $4.551^{* * *}$ & .000 & .050 & Supported \\
\hline $\mathrm{H} 2-1$ & Menu $\rightarrow$ Brand image & .118 & $2.334^{*}$ & .020 & .017 & Supported \\
\hline $\mathrm{H} 2-2$ & Price $\rightarrow$ Brand image & .030 & .796 & .426 & .002 & Non-Supported \\
\hline $\mathrm{H} 2-3$ & Food and Beverage $\rightarrow$ Brand image & -.010 & .215 & .830 & .000 & Non-Supported \\
\hline $\mathrm{H} 2-4$ & Employee service $\rightarrow$ Brand image & .029 & .524 & .600 & .001 & Non-Supported \\
\hline $\mathrm{H} 2-5$ & Atmosphere $\rightarrow$ Brand image & .200 & $3.821^{* * *}$ & .000 & .034 & Supported \\
\hline $\mathrm{H} 3$ & Overall quality $\rightarrow$ Brand image & .496 & $10.572^{\star \star \star}$ & .000 & .283 & Supported \\
\hline $\mathrm{H} 4$ & Overall quality $\rightarrow$ Loyalty & .369 & $7.461^{* * *}$ & .000 & .147 & Supported \\
\hline \multirow[t]{5}{*}{$\mathrm{H} 5$} & Brand image $\rightarrow$ Loyalty & .422 & $8.590^{* * * t}$ & .000 & .191 & Supported \\
\hline & & \multicolumn{3}{|c|}{$\mathrm{R}^{2}$} & \multicolumn{2}{|r|}{$\mathrm{Q}^{2}$} \\
\hline & Overall quality & \multicolumn{3}{|c|}{.485} & \multicolumn{2}{|c|}{.387} \\
\hline & Brand image & \multicolumn{3}{|c|}{.553} & \multicolumn{2}{|c|}{.456} \\
\hline & Loyalty & \multicolumn{3}{|c|}{.535} & \multicolumn{2}{|c|}{.447} \\
\hline
\end{tabular}

$p<.001,{ }^{* *} p<.01 ; \stackrel{p}{*}<.05$

\section{Appendix 5: Mediation Test Using Bootstrapping}

\begin{tabular}{|l|c|c|c|}
\hline \multicolumn{1}{|c|}{ Paths } & Direct effect(t-value) & Indirect effect(t-value) & Mediating role \\
\hline Menu $\rightarrow$ Overall quality $\rightarrow$ Brand image & $.118^{*}$ & $.114(4.148)^{* * *}$ & Partial mediator \\
\hline Price $\rightarrow$ Overall quality $\rightarrow$ Brand image & .030 & $.061(2.937)^{* *}$ & Full mediator \\
\hline Food and beverage $\rightarrow$ Overall quality $\rightarrow$ Brand image &. .010 & $.058(2.380)^{*}$ & Full mediator \\
\hline Employee service $\rightarrow$ Overall quality $\rightarrow$ Brand image & .029 & $.075(2.967)^{* *}$ & Full mediator \\
\hline Atmosphere $\rightarrow$ Overall quality $\rightarrow$ Brand image & $.200^{* * *}$ & $.127(4.147)^{* * *}$ & Partial mediator \\
\hline Overall quality $\rightarrow$ Brand image $\rightarrow$ Loyalty & $.369^{* * *}$ & $.209(7.090)^{* * *}$ & Partial mediator \\
\hline
\end{tabular}

${ }^{* * *} p<.001,{ }^{* *} p<.01 ;{ }^{*} p<.05$ 